\title{
The Impact of an Exploratory Approach in Teaching Mathematics to the Critical Thinking Skills of Junior High School Students
}

\author{
Saleh Haji ${ }^{1, *}$, Widya Paramita Sari ${ }^{1}$, Zamzaili $^{1}$ and Yumiati ${ }^{2}$ \\ ${ }^{1}$ University of Bengkulu, Indonesia \\ ${ }^{2}$ Universitas Terbuka, Indonesia \\ ${ }^{*}$ Corresponding author.E-mail: salehhaji@unib.ac.id
}

\begin{abstract}
The goal of this study is to evaluate the impact of an exploratory approach on the ability of Bengkulu City junior high school students to think. Experimental research with Posttest-Only Control Group Design is this type of research. The study sample includes 87 8th grade students in the second semester of the 2019/2020 Academic Year at SMPN 1, SMPN 11, and MTs Ja-Al Haq. On the basis of Kruskal Wallis H. Review, the asymp Sig is bigger than 0.05 at 0.583 . Therefore, there is little differentiation in the critical thinking abilities of students, which are taught in high, middle, and low level schools using an exploratory approach to teaching mathematics. The average value of the critical reasoning ability of the student from each level of education is as follows: high level school is 53.77; middle school level is 53.45 and 47.63 is around the lower level. In the medium group, the vital potential of junior high school students in Bengkulu is included.
\end{abstract}

\section{Keywords: Approach to discovery, Exploratory approach, Critical thought.}

\section{INTRODUCTION}

There are many benefits to the exploratory approach to learning, namely: 1. Output Increase [1], 2. Increased trust and functional skills [2], 3. Awareness, skills and attitudes are increasing [3]. This is because investigative practices are used by the discovery approach as a central practice. The investigation activities consist of tracing [4], deepening, and proving activities. In learning, information retrieval exercises make students look for different sources of learning that facilitate content comprehension and completion of tasks. Deepening learning experiences allow students attempt to describe a mathematical principle or issue in depth and detail [5]. Proving practices in mathematics learning lets students search for rational arguments and reasons to explain a statement's validity. To achieve good results, tracing and proving tasks undertaken by students in learning mathematics include critical thinking activities. The ability to consider, evaluate, reflect, review knowledge to shape self-setting decisions and objectives in context, and solve problems is critical thinking [6]. In order to solve a problem and get the right decision [7], logical thinking is very important. Currently, problem solving skills of students are very limited [8]. This can be seen from the 2018 PISA results, with
Indonesian students scoring 379 below the 489 average [9].

In this research, the formulation of the issue is as follows: (1) How is critical thinking skills learned by students in an exploratory approach depending on the level of school, (2) Are there variations in the critical thinking abilities of students taught through an exploratory approach dependent on school level.

This research is intended to determine: (1) the critical reasoning capacity of students taught in an exploratory approach focused on the level of the school, and (2) if there are variations in the logical thinking abilities of students taught through an exploratory approach depending on the level of education.

One of the skills required in the 21 st century is the ability to think critically. In this century, the different concerns are very complex. We therefore need individuals with reliable thinking abilities. Critical thinking, imaginative thinking, and reflective thinking skills comprise these abilities. Thinking that includes interpreting, synthesizing, and testing ideas is critical thinking [10].

In the form of drawing conclusions, comparing, and describing critical thought. Synthetic thought takes the form of combined thinking, strategies to create, and alternatives to thinking. In the following figure 1 , the parts of thought are listed. Indicators for 
logical thought are as follows: a) arguments to analyze, b) considering multiple sources, c) deduction research, d) induction evaluate, and e) formulate and infer a hypothesis [12]. It is possible to satisfy these critical thinking metrics with an exploratory approach. The exploratory approach is an approach that aims, through a series of open questions and commands, to discuss various concepts, claims, and ways from students so that students can understand a concept and solve problems [5]. Through exploration of arguments in the exploratory method, the components of critical thinking, such as argument analysis thinking in exploring a phenomenon (object), are created. This is consistent with the 2nd exploration method theory [4]. Like the method of evaluating the relation between the diagonal lines of space and the prism's base plane.

The syntax for the approach to exploration consists of three steps, namely: 1. Step for Training, 2. Fresh Idea Discovery exploration, and 3. New Concept Applications Exploration [13]. The instructor discusses perspectives, initial skills, and diagnoses students in the preparation stage. Before the instructor teaches about prisms, the initial ability to explore the region of a rectangular shape is explored. The teacher corrects them if misconceptions are acquired, before explaining new content. Awareness constructed by relationships between concepts is mathematics [14]. Therefore, the initial stage of this exploratory approach has a very important function and decides the understanding of the next student. The initial stage of this approach to exploration is the stage leading to stage 2, namely the stage of exploration to explore new ideas. The teacher directs students to discover new ideas in this phase [13]. The discovery in mathematics of new ideas may be in the form of finding new ways of solving a problem [15]. The basis for stage 3 , namely the discovery stage for the introduction of new ideas, is given by stage 2 . Students apply the concepts they learned in phase 2 to new situations at this point. In addition, to solve a dilemma, students use the ideas they get in stage 2 [16].

The effects of the exploratory approach on the critical thinking skills of students in the research are problem solving, argument, assessment, and synthesis elements. The effect on the ability to think analysis can be defined by students in several subsystems as a system (unity) (parts). Decomposing the prism into many components, namely: points, lines, and planes. The influence of problem solving on the ability to think is on the ability of students to solve a problem. The effect on the ability to justify is on students' ability to express reasons [17]. For the outcomes of the work they do, students should express reasons. The effect on the ability to evaluate thought is the ability of students to evaluate themselves and evaluate others' work. The influence on the ability to think in synthesis is that students have the ability to integrate different elements into one single whole.

\section{METHODS}

The research method of the study follows the design of critical thinking components [18], as shown in Figure 1.

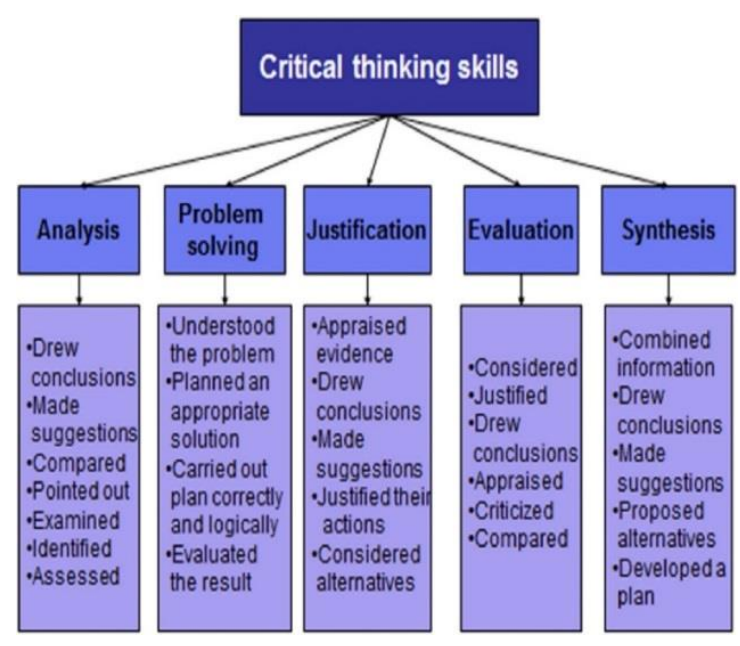

Figure 1. Critical thinking components 
The study sample consisted of 87 SMPN 1 (high level), SMPN 11 (middle level), and MTs Ja-Al Haqq students in grade 8 (lower level). In the same semester as the 2019-2020 Academic Year, research activities are carried out. The research instrument contained as many as 4 items on prisms in the form of essay questions on critical thinking abilities. The instrument trial results showed that for each correlation value (r) the 4 critical thinking questions were true as follows: $\mathrm{r}$ item $1=0.586 \mathrm{r}$ item $2=$ $0.585, \mathrm{r}$ item $3=0.843$, and $\mathrm{r}$ item $4=0.806$ at substantial 0.005 with a measured $r$ value greater than $\mathrm{r}$ table $=0.442$. The real value of Cronbach's Alpha, meanwhile is 0.679 and lies with high reliability parameters in the $0.6<\mathrm{r} 11<0.8$ interval. This demonstrates that the method can be sufficiently accurate to be used in analysis.

\section{RESULTS AND DISCUSSION}

The exploratory approach to prisms in junior high schools carried out in mathematics learning has an impact on critical thinking skills [19]. The critical thinking abilities of students are well established. After studying mathematics using an exploratory approach, the components of the critical thinking of students grow. The analysis, problem solving, reasoning, assessment, and synthesis of these thought components are well developed [11]. The ability of the students to think analysis is illustrated by their ability to define the elements of the prism, namely: loading similar and $n$-shaped base and upper planes, $n+2$ sides, $3 n$ edges, $2 n$ vertices of $n(n-1)$ planes, and $n(n-3)$ space diagonals.

The desire to think about problem solving is well illustrated by students in solving problems. The exploratory approach has an effect on thinking skills in problem-solving [20]. The issue with the answer of the following question number 1 .

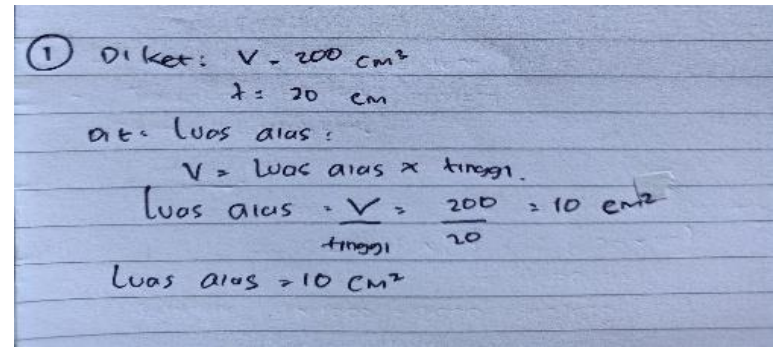

Figure 2. Problem solving by students 1

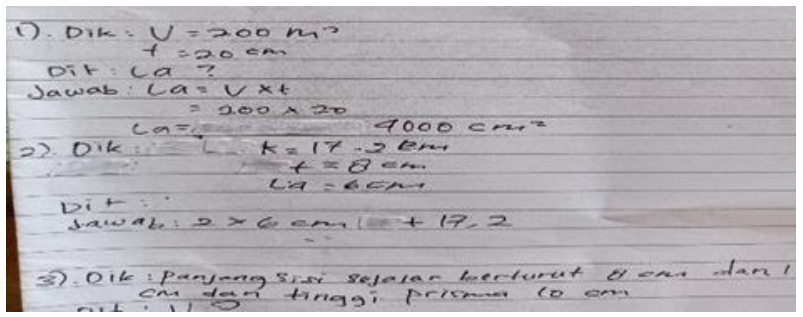

Figure 3. Problem solving by students 1

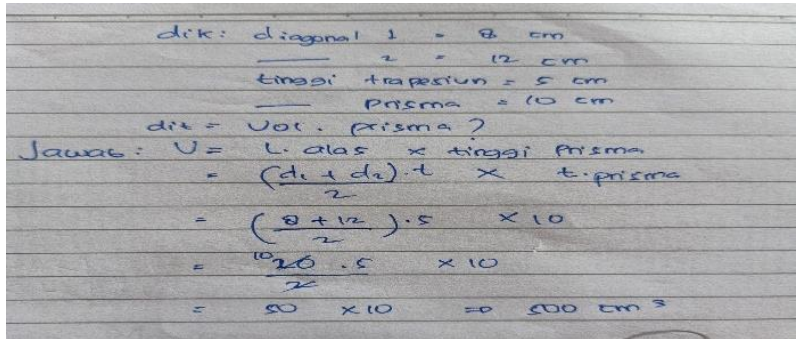

Figure 4. Problem solving by students 1 
Table 1. Students' critical thinking skills based on school level

\begin{tabular}{llll}
\hline & School A & School B & School C \\
\hline N & 26 & 32 & 29 \\
Skor min & 45 & 5 & 38 \\
Skor maks & 65 & 85 & 85 \\
Mean & 53.77 & 47.63 & 53.45 \\
SD & 6.08 & 22.93 & 11.57 \\
\hline
\end{tabular}

Table 2. Test of critical thinking skills

\begin{tabular}{ll}
\hline & Critical score \\
\hline Kruskal-Wallis H & 1,078 \\
df & 2 \\
Asymp. Sig & .583 \\
\hline
\end{tabular}

The tendency to believe that students are justified is illustrated by presenting explanations for the outcomes of their work [21]. Giving students reasons through the application of the prism material formula to assess the area of the base of a prism. In determining the incorrect job outcomes, students display the ability to think judgments. In the misunderstanding of the prism material formula, the mistake lies. The capacity of students to synthesize thought is demonstrated by mixing different elements [22]. Prism was used to assess the prism's volume. As seen by the students who follow.

Overall, the critical thinking skills of the students at the upper level were 53.77, the middle level was 53.45 , and the lower level was 47.63 , respectively. The critical thinking abilities of students at the upper, middle and lower levels of school did not vary substantially. This illustrates that at the upper, middle and lower levels of education, the exploratory approach has the same effect on the critical thinking abilities of students. The critical thinking abilities of students at the upper, middle and lower school levels are shown in Table 1.

The value of Asymp was obtained based on the Kruskal-Wallis $\mathrm{H}$ test. Sig is 0.583 greater than 0.05 , but there is no disparity in the critical reasoning abilities of students that are taught at high, middle and lower school levels using an exploratory approach to teaching mathematics, as shown in Table 2.

\section{CONCLUSIONS}

This study's findings are as follows: (1) the critical thinking skills of students at high level schools are 53.77, b. At high level schools, students' critical thinking capacities are 53.45, and c. At high level schools, the critical thinking skills of students were 47.63 , (2) there is no variation in the critical thinking skills of students, which are taught using an exploratory approach, depending on school level. In teaching mathematics, an exploratory approach should be used to build critical thinking skills for students that consist of logical thinking skills, problem solving, justification, assessment, and synthesis.

\section{REFERENCES}

[1] Vamplew, Dazeley, P., \& Foale, C. (2016). Softmax Exploration Strategies for Multiobjective Reinforcement Learning. Neurocomputing. 10.1016/j.neucom.2016.09.141

[2] Hershkovitz, A. \& Karni, O. (2018). Borders of change: A holistic exploration of teaching in one-to-one computing programs, Computers \& Education. doi: 10.1016/ j.compedu.2018.06.026.

[3] Lin, C.C., Han, C.Y., Pan, I.J., Chen, L.C. (2014). The teaching-learning approach and critical thinking development: A qualitative exploration of Taiwanese nursing students. Journal of Professional Nursing, Vol. 10, pp. $1-9$. 
[4] Gebhard, J. G. (2005). Teacher development through exploration: Principles, Ways, and Examples. The electronic Journal for English as a Second Language, Volume 9, Number 2, September 2005.

[5] Rohaeti, E. E. (2008). Pembelajaran melalui pendekatan eksplorasi untuk mengembangkan kemampuan berpikir kritis dan kreatif matematik siswa SMP. Disertasi. Program Pascasarjana UPI Bandung.

[6] Facione, P. A. (2011). Critical thinking: What it is and why it counts. Millbrae: Measured Reasons and The California Academic.

[7] Castle, A. (2009). Defining and assessing critical thinking skills for student radiographers. Radiography 15.

[8] Soedjadi, R. (2000). Kiat Pendidikan Matematika di Indonesia. Jakarta: Departemen Pendidikan Nasional.

[9] OECD (2018). PISA Result in Focus. http://www.oecd.org/pisa/pisa-2015-resultsin-focus.

[10] Gokhale, A.A. (1995). Collaborative Learning Enhances Critical Thinking. [Online]. Tersedia: http://scholer.lib.vt.edu/ejournals/

[11] Pieterse, T., Lawrence, H., \& Frederich-Nel, H. (2016). Critical thinking ability of $3^{\text {rd }}$ year radiography students. ScienceDirect. www.sciencedirect.com.

[12] Baron, J.B. \& Stenberg, R.J. (1987). Teaching Thinking Skill. New York: W.H. Freeman and Company.

[13] Rohaeti, E.E., Hendriana, H., Sumarmo, U. (2019). Pembelajaran Inovatif Matematika Bernuansa Pendidikan Nilai dan Karakter. Bandung: Refika.

[14] Watson, A. \& Mason, J. (2005). Mathematics as A Construktive Activity. London: Lawrence Arlbaum Associates, Publishers.

[15] Nohda, N. (2000). Teaching by Open Approach, method in Japanese mathematics classroom. In Proceedings of the PME-24 Conference, Vol. 1, 39-53, Hiroshima University, Japan.
[16] Lin, C.C., Han, C.Y., Pan, I.J., Chen, L.C., (2014). The teaching-learning approach and critical thinking development: A Qualitative exploration of Taiwanese nursing students. Journal of Professional Nursing, Vol. 10, No. 0 (August), 2014, pp. 1-9, Elsevier Inc.

[17] Hung, Y.H. (2020). Exploration of teachers' personal practical knowledge for teaching controversial public issues in elementary school classrooms. The Journal of Sosial Studies Research, Volume 44, Issue 3, Pages 281-289.

[18] Borg, W.R. \& Gall, M.D. (1983). Educational Research. London: Longman.

[19] Liang, W., Fung, D. (2020). Development and evaluation of webquest-based teaching programme: Students' use of exploratory talk to exercise critical thinking. International journal of educational research, Volume 104.

[20] Woo, E.M.W., Serenko, A., Chu, S.K.W., (2019). An exploratory study of the relationship between the use of the learning commons and students' perceived learning outcomes. The Journal of Academic Librarianship, Volume 45, Issue 4, Pages 413419.

[21] Yumiati and Haji, S. (2019). Promoting understanding ability of semigroup concept through learning model of concept attainment. Journal of Physics: Conference Series. Ser. 1315012089.

[22] Haji, S. (2017). Development of the basic concepts of mathematics using outdoor learning in primary school. Proceedings the $2^{\text {nd }}$ International Conference on Basic Education and Early Childhood. April 15, 2017, Indonesia University of Education, Serang Campus, Indonesia. 